\title{
Comparison of two methods for glucocorticoid evaluation in maned wolves ${ }^{1}$
}

\author{
Angélica S. Vasconcellos ${ }^{2 *}$, Marie-Odile M. Chelini², Rupert Palme ${ }^{3}$, Marcelo A.B.V. \\ Guimarães ${ }^{4}$, Cláudio A. Oliveira ${ }^{4}$ and César Ades $^{2}$
}

\begin{abstract}
Vasconcellos A.S., Chelini M.O.M., Palme R., Guimarães M.A.B.V., Oliveira C.A. \& Ades C. 2011. Comparison of two methods for glucocorticoid evaluation in maned wolves. Pesquisa Veterinária Brasileira 31(Supl.1):79-83. Department of Experimental Psychology, Institute of Psychology, University of São Paulo, Av. Professor Mello de Moraes 1721, São Paulo, SP 05508-030, Brazil. E-mail: angelv@usp.br

Analysis of faecal glucocorticoid metabolites provides a powerful noninvasive tool for monitoring adrenocortical activity in wild animals. However, differences regarding the metabolism and excretion of these substances make a validation for each species and sex investigated obligatory. Although maned wolves (Chrysocyon brachyurus) are the biggest canids in South America, their behaviour and physiology are poorly known and they are at risk in the wild. Two methods for measuring glucocorticoid metabolites in maned wolves were validated: a radio- and an enzyme immunoassay. An ACTH challenge was used to demonstrate that changes in adrenal function are reflected in faecal glucocorticoid metabolites. Our results suggest that both methods enable a reliable assessment of stress hormones in maned wolves avoiding short-term rises in glucocorticoid concentrations due to handling and restraint. These methods can be used as a valuable tool in studies of stress and conservation in this wild species.
\end{abstract}

INDEX TERMS: ACTH, corticosterone, cortisol, immunoassay, non-invasive monitoring, stress.

RESUMO.- [Comparação de dois métodos para avaliação de glicocorticóides em lobos guarás.] A análise de metabólitos de glicocorticóides fecais é uma ferramenta não-invasiva poderosa para o monitoramento da atividade adrenal em animais silvestres. Entretanto, diferenças no metabolismo e na excreção dessas substâncias tornam obrigatória a validação desse método para cada espécie e sexo investigado. Embora os lobos guarás (Chrysocyon brachyurus) sejam os maiores canídeos da América do Sul, seu comportamento e fisiologia são ainda pouco conhecidos e estes animais são ameaçados. Dois métodos para mensuração de metabólitos de glicocorticóides em lobos guarás

\footnotetext{
${ }^{1}$ Received on March 25, 2011.

Accepted for publication on December 12, 2011.

${ }^{2}$ Departamento de Psicologia Experimental, Instituto de Psicologia, Universidade de São Paulo (USP), Av. Prof. Mello de Moraes 1721, São Paulo, SP 05508-030, Brazil. *Corresponding author: angelv@usp.br

${ }^{3}$ Department of Biomedical Sciences/Biochemistry, University of Veterinary Medicine, Veterinärplatz 1, A-1210 Vienna, Austria.

${ }^{4}$ Departmento de Reprodução Animal, Faculdade de Medicina Veterinária e Zootecnia (FMVZ), Universidade de São Paulo (USP), Av. Prof. Dr. Orlando Marques de Paiva 87, São Paulo, SP 05508-270, Brazil.
}

foram validados: um radio- e um enzima- imuno-ensaio. Um desafio de ACTH foi usado para demonstrar que alterações no funcionamento adrenal podem ser detectadas nas concentrações metabólitos de glicocorticóides fecais. Nossos resultados sugerem que ambos os métodos possibilitam uma avaliação confiável dos hormônios relacionados ao estresse em lobos guarás, evitando assim aumentos de curta duração nas concentrações glicocorticóides, devidos ao manejo e contenção. Esses métodos podem ser usados como uma ferramenta valiosa em estudos de estresse e conservação com essa espécie silvestre.

TERMOS DE INDEXAÇÃO: ACTH, corticosterona, cortisol, imuno-ensaio, monitoramento não-invasivo, estresse.

\section{INTRODUCTION}

Glucocorticoids are released in response to environmental challenges to overcome stressful situations. Their functions include increasing available glucose, improving cardiovascular tone, and inhibiting the gastrointestinal, reproductive and immune systems. The associated cascade of hormones through the blood, known as the hypothalamic-pituitary- 
-adrenal (HPA) axis, is activated by a wide variety of environmental and social stressors, in particular, exposure to novelty and lack of predictability or controllability of important events (Sapolsky 1992, Möstl \& Palme 2002). Acute and chronic stress can have deleterious effects on survival or reproduction. Knowledge of stress hormones is, therefore, important for conservation biology, wildlife management, animal husbandry, behavioural ecology and biomedical studies (Boonstra \& Singleton 1993, Graham \& Brown 1996, Wingfield et al. 1997, Touma \& Palme 2005, Thiel et al. 2008).

Research on stress in wild animals has been aided greatly by the development of techniques to monitor glucocorticoids noninvasively, often by using faecal glucocorticoid metabolites (GCM). Faecal samples can be acquired with minimal or no contact with study animals, avoiding increases in circulating glucocorticoid levels as a result of handling. Another advantage is that longitudinal sample collection is possible and enables studies connecting endocrinology with a wide range of social or environmental factors. Finally, noninvasive methods allow information to be obtained retrospectively, as faecal samples represent average hormone production a certain time ago (Touma \& Palme 2005). Researchers and conservationists in various animal species (for a review, see Touma \& Palme 2005, Schwarzenberger 2007) have extensively used these techniques, which are now widely accepted as effective for monitoring glucocorticoid levels. However, using these techniques to reliably assess an animal's adrenocortical activity is not that simple and straightforward to apply. Because clear differences regarding the metabolism and excretion of GCM exist between species, and sometimes even between sexes within a given species (Palme et al. 2005), a careful validation for each species and sex investigated is obligatory (Palme 2005, Touma \& Palme 2005).

During the last decades, radioimmunoassays (RIAs) have been progressively replaced in human medicine by more modern and ecologically correct methods, such as fluorescence immunoassays or enzyme immunoassays (EIA). However, despite the considerable disadvantages of the former technique if compared to enzyme immunoassays, associated with the use of radioisotopes, risk in their transportation from abroad, high costs, and the need for special environmental conditions (temperature, humidity, etc.) in the laboratories where they are finally used (Mondal \& Prakash 2007), radioimmunoassays are even nowadays mainly used in animal research for measuring steroids in blood and faeces in several countries, probably due to the relative ease of acquisition. These countries do not have easy access to the large variety of group specific EIA antibodies provided by a few laboratories in the world, and do not have facilities to produce their own. Therefore, both techniques were tested, in order to make it feasible to noninvasively measure glucocorticoids in maned wolves (Chrysocyon brachyurus) even in laboratories with restricted access to specific immunoassay techniques.

The maned wolf is the largest canid in South America and, in spite of its ample distribution in South America (Brazil, Argentina, Bolivia, and Paraguay, Dietz 1984), the population size in the wild is threatened (Dietz 1984, Bec- caceci 1991, IUCN 2009), mainly by large-scale habitat loss, due to deforestation and conversion to agricultural land (Fonseca et al. 1994). Due to this threat, the establishment of a stable ex situ population is essential from a conservation perspective. However, according to the International Register and Studbook for the Maned Wolf (2002), the captive population of maned wolves is not self-sustaining.

Lack of environmental novelty and complexity, common in captive contexts, may lead to low welfare (Young 2003). Severe and chronic stress may reduce individual fitness through immunosuppression and tissue atrophy (Munck et al. 1984), also diminishes the animal's reproductive success (Liptrap 1993, Dobson \& Smith 1995).

Several authors used faecal GCM quantification to assess stress responses in domestic dogs (Palme et al. 2001, Schatz \& Palme 2001), African wild dogs (Monfort et al. 1998), spotted hyenas (Goymann et al. 1999), grey wolves (Sands $\&$ Creel 2004) and red wolves (Young et al. 2004). Cummings et al. (2007) studied the physiological and behavioural responses of the maned wolf to environmental enrichment. However, a physiological validation of their techniques to measure stress hormone metabolites in this species is missing in their paper. As there is limited specific information about maned wolf stress physiology, increased knowledge would improve captive breeding and management. Therefore, the hypothesis that RIA and EIA can accurately measure adrenocortical activity in the study species was tested. For the first time, both methods for measuring faecal GCM in maned wolves were validated biochemically and physiologically (Touma \& Palme 2005, Chelini et al. 2011).

\section{MATERIALS AND METHODS}

\section{Animals}

Faecal samples from 2 adult captive-born maned wolves were collected during the summer of 2008 (out of the breeding season in the Southern Hemisphere). As sex may play a role in the metabolism and excretion of steroids (Palme et al. 2005), a male-female pair was used. The wolves had been pair-housed for the previous five years at São Bernardo do Campo Zoo, in the State of São Paulo (Brazil). The enclosure measured $490 \mathrm{~m}^{2}$, containing grass, trees, and 2 dog houses. The wolves were fed once a day, in the morning, a meal consisting of seasonal fruits (apple, banana, papaya) and meat (bovine heart, chicken neck, moist dog food or slaughtered laboratory rats). Water was provided ad libitum.

\section{Collection of faeces}

Fresh faecal samples were collected daily around 9:00 h, for 11 days (5 days prior to an adrenocorticotropic hormone [ACTH] injection and 6 days following this procedure). As these canids normally defecate once or twice a day, the samples collected at this time would reflect adrenocortical activity in the previous day. In the afternoons, the female was fed with a meatball with powder food dye, to permit identification of individual faecal samples. Every faecal sample was mixed immediately after collection to ensure sample homogeneity, and frozen $\left(-20^{\circ} \mathrm{C}\right)$ until extraction.

\section{Determination of faecal GCM}

Radioimmunoassay. The steroid extraction method of Brown et al. (1994) was used, as already described for maned wolves (Cummings et al. 2007), with minor modifications. Aiming at the possibility of avoiding the costs and the spending of unnecessary time in 
lyophilisation, a pilot test was run, comparing a set of 12 wet and the corresponding 12 dried (lyophilized) extra samples. As the results were highly correlated, nondried faecal samples $(0.3 \mathrm{~g})$ were boiled for $20 \mathrm{~min}$ in $5 \mathrm{~mL} 90 \%$ ethanol: $10 \%$ distilled water. Each sample was centrifuged at $500 \mathrm{x}$ g for $15 \mathrm{~min}$, the supernatant was recovered, the pellet was resuspended in $5 \mathrm{~mL}$ of $90 \%$ ethanol and re-centrifuged at $500 \mathrm{x}$ g for $15 \mathrm{~min}$. The supernatant was recovered, pooled with the previous one, dried and resuspended in $1 \mathrm{~mL}$ methanol $(100 \%)$. The extracts were stored frozen $\left(-20^{\circ} \mathrm{C}\right)$ until analysis.

GCM were quantified using a commercially available double-antibody corticosterone radioimmunoassay kit (MP Biomedicals, Irvine, CA), following the manufacturer's protocol. This assay was shown to be able to detect changes in adrenocortical activity in a wide range of species (for a review, see Touma \& Palme 2005). Wasser et al. (2000) and Heistermann et al. (2006) report detailed crossreactions of the antibody with various GCM. Before analysis, faecal extracts were diluted in RIA diluent (1:100 and $1: 20$, when necessary). Faecal concentrations of GCM measured by RIA were expressed as micrograms per gram wet faeces. In order to establish the biochemical validity of our assay, a test of parallelism was performed: samples serially diluted were pooled with the steroid diluent provided with the corticosterone RIA kit to compare the slope of the antibody binding curve with that of the standard supplied with the RIA kit.

Enzyme Immunoassay. The steroid extraction method recommended by Palme (2005) was used. The amounts of GCM were determined using a cortisol EIA, previously described by Palme and Möstl (1997). This assay has already been validated and successfully used with dogs' faeces to monitor changes in adrenocortical activity (Schatz \& Palme 2001). Faecal concentrations of GCM measured by EIA were expressed as nanograms per gram wet faeces.

\section{ACTH-challenge test}

This validation procedure involved monitoring of faecal GCM before and after an exogenous administration of ACTH, in order to demonstrate a temporal correlation between changes in adrenal activity and changes in faecal GCM concentrations. Each maned wolf was administrated an intramuscular injection of $0.38 \mathrm{mg}$ of a synthetic ACTH (Synacthen $1 \mathrm{mg} / \mathrm{ml}$; Novartis Farma S.p.A, Origgio, VA). The day of injection was referred as day 0 , with faecal collection beginning on day -4 and continuing to day 6 .

The experiment was conducted in accordance with the Brazilian ethical guidelines. It also had the approval of the Committee for Ethics in Animal Research, Institute of Psychology, University of São Paulo (permit number 001.2009).

\section{Statistics}

Pearson's Correlation Coefficient was used to evaluate the correlation between metabolite concentrations in wet and lyophilized samples (pilot test), the concentrations measured in the faeces of the female and the male, and between the results obtained with both techniques for each individual. A T-Test was used to compare the baseline mean concentrations of GCM of males and females and a Linear Regression was used to check for parallelism between the slopes of the commercial kit standard and the dilutions of the faecal extracts.

Faecal GCM measures from each individual were analysed separately. For each animal, baseline level was calculated as the mean of GCM concentrations measured through the days prior to injection. Increases in GCM excretion after ACTH injection were considered significant if they exceeded mean baseline concentration plus 2 standard deviations. For all statistical tests, differences were considered significant at $P \leq 0.05$, which were performed using GraphPad InStat (version 3.00, GRAPHPAD Software Inc. 2000).

\section{RESULTS}

\section{Biochemical validation of the assays}

The pilot test revealed a positive correlation between the concentrations measured by RIA in the wet and in the dried samples $(r=0.89, P \leq 0.001)$. Serial dilutions of pooled faecal extracts, measured by RIA, produced displacement curves parallel to those of the corticosterone standard curve: $r=0.998(\mathrm{y}=2.485+0.896 \mathrm{x}), P \leq 0.001$. The sensitivities of the assays were $6.43 \mathrm{ng} / \mathrm{g}$ (RIA) and $0.7 \mathrm{ng} / \mathrm{g}$ (EIA) and all the coefficients of variation were below $10 \%$.

\section{GCM concentrations}

The animals maintained an average concentration ( \pm SD) of $14.7 \pm 12.4 \mu \mathrm{g} / \mathrm{g}$ faeces (Female, RIA); $37.9 \pm 56.7 \mathrm{ng} / \mathrm{g}$ faeces (Female, EIA), $11.3 \pm 7.3 \mu \mathrm{g} / \mathrm{g}$ faeces (Male, RIA) and 32.1 $\pm 31.7 \mathrm{ng} / \mathrm{g}$ faeces (Male, EIA) throughout the baseline period, without differences between mean values of males and females $(t=0.5234, P=0.6148$ for RIA and $t=0.2013, P=0.8455$ for EIA). The ACTH treatment resulted in an increase (to $60 \mu \mathrm{g} / \mathrm{g}$ faeces - Female, RIA; $220 \mathrm{ng} / \mathrm{g}$ faeces - Female, EIA; $42 \mu \mathrm{g} / \mathrm{g}$ faeces - Male, RIA and $211 \mathrm{ng} / \mathrm{g}$ faeces - Male, EIA) in GCM concentrations from day 0 to day 1 and a decrease from days 1 to 2 and 2 to 3 , when concentration returned to baseline (Fig.1a,b). In both animals, peak values were observed in the first day
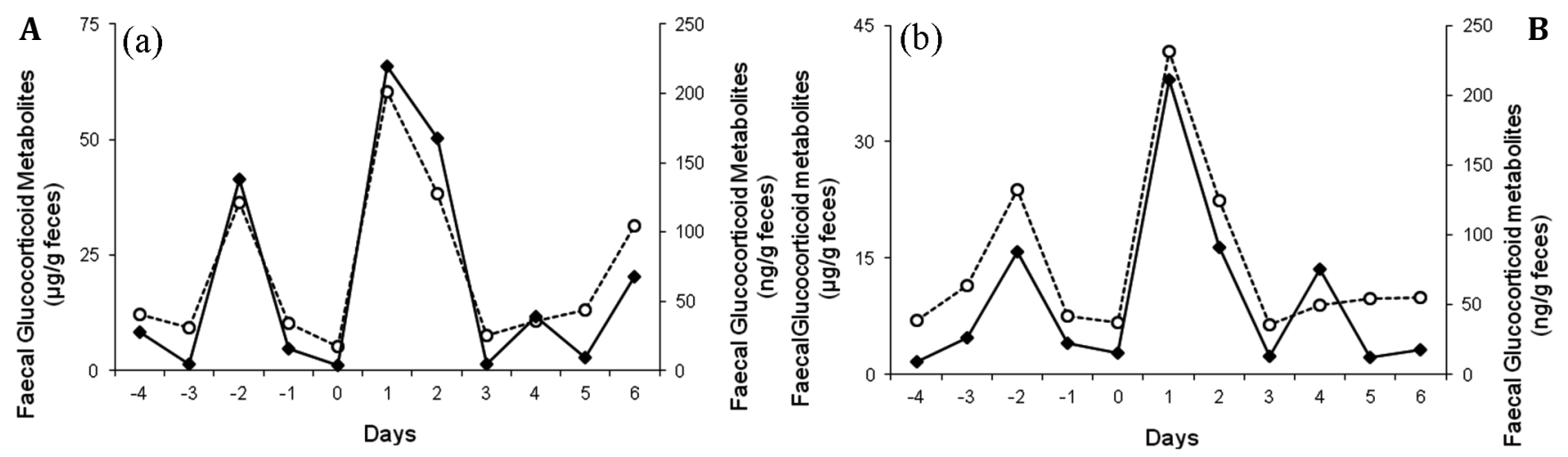

Fig.1. Concentrations of faecal glucocorticoid metabolites (GCM) of a female $(a)$ and a male $(b)$ captive maned wolf (Chrysocyon brachyurus) during an adrenocorticotropic hormone (ACTH) challenge measured by radio- (--0--) and enzyme immunoassay (- - -). Samples were collected in the Summer 2008 at the São Bernardo do Campo Zoo, Brazil. Day zero represents the day of injection (0.38 mg, intramuscular). 
following the ACTH challenge, which reached between $268 \%$ and $557 \%$ of the baseline concentration. Statistical analysis evidenced correlations between male and female data $(r=0.93$; $P \leq 0.0001$ with RIA and $r=0.89 ; P \leq 0.0001$ with EIA) as well as between data resulting from EIA and RIA for each individual $(r=0.97 ; P \leq 0.0001$ for Female and $r=0.95$ and $P \leq 0.0001$ for Male). Both animals had relatively high concentrations of GCM on day -2 for unknown reasons. However, the GCM concentrations on this day did not exceed the pre-set level of significance (mean baseline plus 2 SD).

\section{DISCUSSION}

Our results demonstrated that, in maned wolf, adrenocortical activity is well reflected in GCM concentrations. In both animals, either through RIA or EIA, a peak value was observed on the first day following the ACTH challenge, which reached between $268 \%$ and $557 \%$ of the baseline concentration. GCM concentrations returned to basal level 3 days after the injection. These results are consistent with the findings of Schatz \& Palme (2001). These authors used the same cortisol EIA in domestic dogs' faeces, and measured an increase in concentrations of cortisol metabolites above baseline of approximately $700 \%$ about $22 \mathrm{~h}$ after ACTH administration. Therefore, the delay time of peak concentrations is similar in the 2 species, which suggests a similar excretion pattern between maned wolves and domestic dogs.

Because the maned wolf is near threatened, it was not possible to work with a larger sample and perform a control study. As high inter-animal variation in GCM concentration were reported in similar studies (Schatz \& Palme 2001, Chelini et al. 2006, Cummings et al. 2007), a 5-day baseline period was included, so that each animal could serve as its own control (Touma \& Palme 2005). For the same reason, it was not possible to assess the effect of the injection procedure itself by injecting other wolves with saline solution. Therefore, it is not possible to state that the increase in GCM concentration on day 1 did not result from the stressful effects of the injection procedure itself instead of or in addition to the ACTH stimulation. However, both situations fit our purpose by elevating circulating levels of glucocorticoids. Likewise, the relatively high GCM concentration measured in day -2 samples from both animals probably reflected an increase in blood glucocorticoid levels on the previous day. As the pair was housed in the same enclosure, it is likely that any stressful event affecting one animal on day - 3 would affect the other one and result in an increase in blood glucocorticoids that was reflected in faecal GCM concentration on the following day, as observed. As the animals were not observed continuously during this period, it was not possible to identify such an event.

The correlation between male and female data using both techniques suggests that there are no sex differences in glucocorticoid excretion in maned wolves. However, although similar observations were reported for other species such as red-deer (Huber et al. 2003), guinea pigs (Bauer et al. 2008) or wolves (Sands \& Creel 2004), due to the small number of animals available for this study, this outcome should be taken carefully. Studies using more maned wolves will be necessary to generalize this result.
For the first time in this species, a physiological validation of 2 methods for noninvasively assessing adrenocortical activity was presented. It indicates that Chrysocyon brachyurus produces glucocorticoid metabolites in detectable concentrations in faeces and that both - a corticosterone RIA as well as a cortisol EIA are suited to accurately measure glucocorticoids metabolites in the faeces, despite the fact that there is probably only very few cortisol and corticosterone, if any, in the faeces (Touma \& Palme 2005). Cross-reactions of the antibodies (Palme \& Möstl 1997, Heistermann et al. 2006) with one or several GCM may explain this.

Besides avoiding radioactivity, an EIA has several advantages over conventional RIA: it is cheaper, less labour intensive, simpler to perform, less time consuming, and can be especially designed for measuring specific groups of GCM (Möstl et al. 2005, Mondal \& Prakash 2007). Considering the high correlation between the results of the assays, both are equally suited and researchers can decide which one to use, depending on the ease of availability.

Our data indicate that quantification of faecal GCM through either EIA or RIA is a powerful alternative for noninvasive monitoring of free-living or captive maned wolves' responses to environmental and social stressors. These techniques allow stress hormones monitoring without the influence of short-term rises in glucocorticoid concentrations due to handling and restraint. As a consequence, they can be especially useful to predict or interpret behavioural responses to stressors, such as when testing hypotheses about population dynamics, predator-prey relationships, and conservation strategies.

Acknowledgements.- We thank São Bernardo do Campo Zoo, that allowed us to do the research at its facilities, and its staff for the cooperation with this project, as well as Fundação de Amparo à Pesquisa do Estado de São Paulo (FAPESP) for funding this project. We also thank P. Viau and E. Klobetz-Rassam for helping with the analysis of the faecal glucocorticoid metabolites.

\section{REFERENCES}

Bauer B., Palme R., Machatschke I.H., Dittami J. \& Huber S. 2008. Non-invasive measurement of adrenocortical and gonadal activity in male and female guinea pigs (Cavia aperea f. porcellus). Gen. Comp. Endocrinol. 156:482-489.

Beccaceci M.D. 1991. The maned wolf, Chrysocyon brachyurus, in Argentina, p.50-56. In: Matern B. (Ed.), Internacionales Zuchtbuch für den Mähnenwolf, Chrysocyon brachyurus (Illiger, 1811). Frankfurt Zoological Gardens, Frankfurt.

Boonstra R. \& Singleton G.R. 1993. Population declines in the snowshoe hare and the role of stress. Gen. Comp. Endocrinol. 91:126-143.

Brown J.L., Wasser S.K., Wildt D.E. \& Graham L.H. 1994. Comparative aspects of steroid hormone metabolism and ovarian activity in felids, measured non-invasively in feces. Biol. Reprod. 51:776-786.

Chelini M.O.M., Souza N.L., Cortopassi S.R.G., Felippe E.C.G. \& Oliveira C.A. 2006. Assessment of the physiologic stress response by quantification of fecal corticosteroids. J. Am. Assoc. Lab. Anim. Sci. 45:8-11.

Chelini M.O.M., Oliveira C.A. \& Otta E. 2011. Validação de um radioimunoensaio para a quantificação de metabólitos fecais de testosterona em hamster Sírio (Mesocricetus auratus). Pesq. Vet. Bras. 31:459-463.

Cummings D., Brown J.L., Rodden M.D. \& Songsasen N. 2007. Behavioral and physiologic responses to environmental enrichment in the maned wolf (Chrysocyon brachyurus). Zoo Biol. 26:331-343. 
Dietz J.M. 1984. Ecology and social organization of the maned wolf (Chrysocyon brachyurus). Smith. Contrib. Zool. 392:1-51.

Dobson H. \& Smith R.F. 1995. Stress and reproduction in farm animals. J. Reprod. Fertil. 49(Suppl.):451-461.

Fonseca G.A.B., Rylands A.B., Costa C.M.R., Machado R.B. \& Leite Y.R. 1994. Red Book of the Threatened Mammals. Fundação Biodiversitas, Belo Horizonte. 459p.

Goymann W., Mostl E., Van't Hof T., East M.L. \& Hofer H. 1999. Noninvasive fecal monitoring of glucocorticoids in spotted hyenas, Crocuta crocuta. Gen. Comp. Endocrinol.114:340-348.

Graham L.H. \& Brown J.L. 1996. Cortisol metabolism in the domestic cat and implications for non-invasive monitoring of adrenocortical function in endangered felids. Zoo Biol. 15:71-82.

Heistermann M., Palme R. \& Ganswindt A. 2006. Comparison of different enzyme-immunoassays for assessment of adrenocortical activity in primates based on fecal analysis. Am. J. Primatol. 68:257-273.

Huber S., Palme R., Zenker W. \& Möstl E. 2003. Non-invasive monitoring of the adrenocortical response in red deer. J. Wildlife Manage. 67:258-266.

International Union for Conservation of Nature IUCN 2009. Red List of Threatened Species IUCN July. <http://www.iucnredlist.org>

Liptrap R.M. 1993. Stress and reproduction in domestic animals. Ann. N.Y. Acad. Sci. 697:275-284.

Mondal M. \& Prakash B.S. 2007. Highly sensitive second-antibody enzyme immunoassay for determination of estradiol- $17 \beta$ concentration in blood plasma of the mithun (Bos frontalis). Zool. Sci. 24:408-413.

Monfort S.L., Mashburn K.L., Brewer B.A. \& Creel S.R. 1998. Evaluating adrenal activity in African wild dogs (Lycaon pictus) by fecal corticosteroid analysis. J. Zoo. Wildlife Med. 29:129-133.

Möstl E. \& Palme R. 2002. Hormones as indicators of stress. Domest. Anim. Endocrinol. 23:67-74.

Möstl E., Rettenbacher S. \& Palme R. 2005. Measurement of corticosterone metabolites in birds' droppings: An analytical approach. Ann. N.Y. Acad. Sci. 1046:17-34.

Munck A., Guyre P.M. \& Holbrook N.I. 1984. Physiological functions of glucocorticoids in stress and their relationship to pharmacological actions. Endocr. Rev. 5:25-44.

Palme R. 2005. Measuring fecal steroids: Guidelines for practical application. Ann. N.Y. Acad. Sci. 1046:75-80.

Palme R. \& Möstl E. 1997. Measurement of cortisol metabolites in faeces of sheep as a parameter of cortisol concentration in blood. Zeitschrift für Säugetierkunde - Int. J. Mammalian Biol. 62 (Suppl.2):192-197.

Palme R., Rettenbacher S., Touma C., El-Bahr S.M. \& Möstl E. 2005. Stress hormones in mammals and birds: Comparative aspects regarding metabolism, excretion and non-invasive measurement in fecal samples. Trends Comp. Endocrinol. Neurobiol., Ann. N.Y. Acad. Sci. 1040:162-171.

Palme R., Schatz S. \& Möstl E. 2001. Influence of a vaccination on faecal cortisol metabolite concentrations in cats and dogs. Dtsch. Tierärztl. Wochenschr. 108:23-25.

Sands J.L. \& Creel S. 2004. Social dominance, aggression and fecal glucocorticoid levels in a wild population of wolves, Canis lupus. Anim. Behav. 67:387-396.

Sapolsky R.M. 1992. Neuroendocrinology of the stressresponse, p. 287324. In: Becker J.B., Breedlove S.M. \& Crews D. (Eds), Behavioral Endocrinology. MIT Press, Cambridge.

Schatz S. \& Palme R. 2001. Measurement of faecal cortisol metabolites in cats and dogs: A non-invasive method for evaluating adrenocortical function. Vet. Res. Commun. 25:271-287.

Schwarzenberger F. 2007. The many uses of non-invasive faecal steroid monitoring in zoo and wildlife species. Int. Zoo Yearbook 41:52-74.

Thiel D., Jenni-Eiermann S., Braunisch V., Palme R. \& Jenni L. 2008. Ski tourism affects habitat use and evokes a physiological stress response in capercaillie Tetrao urogallus: A new methodological approach. J. Appl. Ecol. 45:845-853.

Touma C. \& Palme R. 2005. Measuring fecal glucocorticoid metabolites in mammals and birds: The importance of validation. Ann. N.Y. Acad. Sci.1046:54-74.

Wasser S.K., Hunt K.E., Brown J.L., Cooper K., Crockett C.M., Bechert U., Millspaugh J.J., Larson S. \& Montfort S.L.A. 2000. A generalized fecal glucocorticoid assay for use in a diverse array of nondomestic mammalian and avian species. Gen. Comp. Endocrinol. 120:260-275.

Wingfield J.C., Hunt K., Breuner C., Dunlap K., Fowler G.S., Freed L. \& Lepson J. 1997. Environmental stress, field endocrinology, and conservation biology, p. 95-131. In: Clemmons J.R. \& Buchholz R. (Eds), Behavioral Approaches to Conservation in the Wild. Cambridge University Press, Cambridge.

Young R.J. 2003. Environmental Enrichment for Captive Animals. Blackwell Science, Oxford. 228p.

Young K.M., Walker S.L., Lanthier C., Waddell W.T., Monfort S.L. \& Brown J.L. 2004. Noninvasive monitoring of adrenocortical activity in carnivores by fecal glucocorticoid analyses. Gen. Comp. Endocrinol. 137:148-165. 